\title{
Evaluation of maternal and fetal outcome in pregnancies complicated by jaundice-an observational study
}

\author{
Ruchi Kishore, Neha Thakur, Mitali Tuwani*
}

Department of Obstetrics and Gynaecology, Pt JNM Medical College, Raipur, Chhattisgarh, India

Received: 03 February 2021

Accepted: 10 March 2021

*Correspondence:

Dr. Mitali Tuwani,

E-mail: m.tuwani@gmail.com

Copyright: (C) the author(s), publisher and licensee Medip Academy. This is an open-access article distributed under the terms of the Creative Commons Attribution Non-Commercial License, which permits unrestricted non-commercial use, distribution, and reproduction in any medium, provided the original work is properly cited.

\begin{abstract}
Background: The spectrum of jaundice in pregnancy varies from a benign condition with good maternal and fetal outcome to a severe form resulting in liver failure and maternal and fetal mortality. Jaundice may complicate 3-5\% of pregnancies. Present study was aimed to analyze the cause, course and impact of jaundice during pregnancy so as to have better understanding and hence better feto-maternal outcome. The present study aimed to analyze the various causes of hepatic dysfunction in pregnancy, maternal and fetal outcome in pregnancies complicated by jaundice and various hematological and liver function variables for predicting maternal and fetal outcome.

Methods: The present study was an observational study conducted in the department of obstetrics and gynecology, Pt. JNM medical college and associated Dr. BRAM hospital, Raipur (CG) over period of 2 year from September 2018 to September 2020.

Results: Total $0.72 \%$ pregnancies were complicated by jaundice. HELLP syndrome was the commonest cause of jaundice in pregnancy $(36.7 \%)$, followed by viral hepatitis $(32.7 \%)$. Hepatitis E was the most common type of viral hepatitis $(91.8 \%)$. Hemolytic jaundice presented with best maternal outcome (maternal mortality rate $8.6 \%$ ). Worst maternal outcome was seen in AFLP (maternal mortality rate 100\%). Best fetal outcome was seen in viral hepatitis (live birth rate 67.6\%), whereas worst noted with AFLP (fetal death rate 66.6\%). Higher total serum bilirubin, higher serum AST, anemia and deranged INR had significant correlation with maternal mortality.

Conclusions: HELLP syndrome and viral hepatitis are preventable causes of jaundice yet it contributed to significant proportion of maternal deaths in 26.5 and $18.5 \%$ cases respectively. AFLP is often under diagnosed and had a fulminant course in pregnancy causing maternal and fetal mortality.
\end{abstract}

Keywords: Jaundice, Pregnancy, Feto-maternal outcome

\section{INTRODUCTION}

Hepatic dysfunction though complicates only $3-5 \%$ of pregnancies but it leads to perinatal mortality in $60 \%$ of cases and maternal mortality in $14 \%$ to $100 \%$ of cases depending upon the cause. ${ }^{1}$

Jaundice can be classified in pregnancy on the basis of jaundice in existing liver diseases, coincidental liver diseases and specific to pregnancy. ${ }^{2}$

\section{Pre-existing liver disease}

Cirrhosis, portal hypertension, autoimmune hepatitis, primary biliary cirrhosis, Wilson's disease, and chronic viral hepatitis A B and C.

\section{Liver diseases coincidental to pregnancy}

Budd Chiari syndrome, acute viral hepatitis A, B, C, and $\mathrm{E}$, alcohol induced liver disease and pregnancy and gallstone causing liver diseases. 


\section{Liver diseases unique to pregnancy}

Cholestasis of pregnancy, Acute fatty liver of pregnancy, Preeclampsia, Eclampsia and HELLP syndrome. Pregnancy is characterized by number of physiological changes in various organs including liver. ${ }^{3}$

Table 1: Physiological changes in liver profile during pregnancy.

\begin{tabular}{|c|c|}
\hline Physiological changes \\
\hline \multirow{2}{*}{ Increases } \\
$\begin{array}{l}\text { Alkaline phosphatase level rise three to } \\
\text { fourfold because of placental production. } \\
\text { Clotting factors I, II, V, VII, VIII, X and } \\
\text { XII. } \\
\text { Ceruloplasmin level are increased } \\
\text { Transferrin level are increased. }\end{array}$ \\
$\begin{array}{l}\text { Gallbladder contractility. } \\
\text { Albumin and protein C levels and } \\
\text { Anti-thrombin III and protein S levels are } \\
\text { decreased }\end{array}$ \\
$\begin{array}{l}\text { Liver transaminase level (AST, ALT). } \\
\text { GGT level, } \\
\text { Bilirubin level, }\end{array}$ \\
\hline Pro-thrombin time remains same.
\end{tabular}

The diagnosis of liver diseases in pregnancy is challenging and relies on laboratory investigations. Signs and symptoms are often nonspecific and consist of jaundice, nausea, vomiting and abdominal pain. Effects of underlying liver disorders are varied ranging from a benign course to a severe form leading to maternal and fetal mortality.

The present study aimed to analyze the various causes of hepatic dysfunction in pregnancy, maternal and fetal outcome in pregnancies complicated by jaundice and various hematological and liver function variables for predicting maternal and fetal outcome.

\section{METHODS}

The present study was an observational study conducted in the Department of Obstetrics and Gynecology, Pt. JNM Medical College and associated Dr. BRAM hospital, Raipur (CG) over period of 2 year from September 2018 to September 2020. Clearance to perform the study was taken by institutional scientific and ethical committee

\section{Inclusion criteria}

All antenatal women with abnormal liver function tests admitted at DR. BRAM hospital were studied during this period and 113 such women were included in this study.

\section{Exclusion criteria}

Women who did not give informed consent for the study were excluded from the study.

\section{Data analysis}

Data was analyzed using SPSS 20.0 statistical software. Receiver operating characteristic (ROC) curves were plotted for hemoglobin, platelet counts, total serum bilirubin, AST, ALT, INR, and their predictive performance with maternal mortality as primary outcome was analyzed. Bivariate analysis of laboratory characteristics with maternal death as primary outcome was noted. All reported $\mathrm{p}$ values are two-tailed and $\mathrm{p}<0.05$ was considered statically significant.

\section{RESULTS}

Table 2 shows the demographic characteristics of the study population. Most of the study subjects were of 2025 years age group $(61.9 \%)$, not booked for antenatal care $(87.6 \%)$, resided in urban area $(76.4 \%)$, belonged to lower socio-economic status $(63.7 \%)$ and were primigravida $(47.7 \%)$.

Table 3 describes the most common clinical symptoms and signs observed in the study population. Yellowish discoloration of urine and sclera $(48.6 \%)$ were the most common presenting symptom, while pallor $(100 \%)$ and Icterus $(98.2 \%)$ were the most common signs observed.

Table 2: Demographic profile of the study subjects in the study population.

\begin{tabular}{|c|c|c|c|}
\hline \multicolumn{2}{|c|}{ Demographic feature } & $\begin{array}{l}\text { No. } \\
(n=113)\end{array}$ & $\%$ \\
\hline \multirow{4}{*}{ Age (years) } & $<20$ & 11 & 9.73 \\
\hline & $20-25$ & 70 & 61.9 \\
\hline & $25-30$ & 24 & 21.2 \\
\hline & $>30$ & 8 & 7.07 \\
\hline \multirow{2}{*}{ ANC care status } & Booked & 14 & 12.38 \\
\hline & Un booked & 99 & 87.6 \\
\hline \multirow{2}{*}{ Residence status } & Rural & 30 & 26.6 \\
\hline & Urban & 83 & 76.4 \\
\hline \multirow{3}{*}{$\begin{array}{l}\text { Seriocomic status } \\
\text { (modified } \\
\text { Kuppuswamy } \\
\text { scale) }\end{array}$} & $\begin{array}{l}\text { Lower } \\
\text { class }\end{array}$ & 72 & 63.7 \\
\hline & $\begin{array}{l}\text { Middle } \\
\text { class }\end{array}$ & 28 & 24.7 \\
\hline & $\begin{array}{l}\text { Upper } \\
\text { class }\end{array}$ & 13 & 11.5 \\
\hline \multirow{5}{*}{$\begin{array}{l}\text { Parity } \\
\text { distribution }\end{array}$} & Primi & 54 & 47.7 \\
\hline & Gravida 2 & 32 & 28.3 \\
\hline & Gravida 3 & 22 & 19.4 \\
\hline & Gravida 4 & 4 & 3.53 \\
\hline & Gravida 5 & 1 & 0.8 \\
\hline
\end{tabular}

Icterus was seen in 111 out of 113 cases, as rest two of the cases had mild increase in bilirubin and icterus was not clinically appreciable.

In two of the eclampsia cases, convulsion was not apparent at the time of admission since these patients were unconscious at that time and convulsed later. 
Table 3: Distribution of study subjects according to clinical symptoms and signs in the study populations.

\begin{tabular}{|lll|}
\hline $\begin{array}{l}\text { Symptoms } \\
\text { Yellowish discoloration } \\
\text { of urine/sclera }\end{array}$ & $\begin{array}{l}\text { No of cases } \\
(\mathbf{n = 1 1 3})\end{array}$ & $\begin{array}{l}\text { Percentage } \\
(\%)\end{array}$ \\
\hline Anorexia & 55 & 48.6 \\
\hline Headache & 38 & 42.4 \\
\hline Loose motions & 30 & 28.3 \\
\hline Nausea and vomiting & 30 & 26.5 \\
\hline Lethargy & 27 & 26.5 \\
\hline Myalgia & 24 & 23.8 \\
\hline Fever & 24 & 21.2 \\
\hline Epigastric pain & 19 & 21.2 \\
\hline Clay stools & 12 & 16.8 \\
\hline Unconsciousness & 12 & 10.6 \\
\hline Convulsion & 12 & 12.3 \\
\hline Pruritus & 11 & 12.3 \\
\hline Arthralgia & 5 & 9.7 \\
\hline Hematemesis & 1 & 4.4 \\
\hline Signs & & 0.8 \\
\hline Pallor & 113 & \\
\hline Icterus & 111 & 100 \\
\hline Edema & 51 & 98.2 \\
\hline Hypertension & 50 & 45.1 \\
\hline Ascites & 27 & 44.2 \\
\hline Abdominal tenderness & 11 & 23.8 \\
\hline Scratch marks & 08 & 9.7 \\
\hline Hepatomegaly & 04 & 7 \\
\hline Splenomegaly & 04 & 3.5 \\
\hline Palmer erythema & 04 & 3.5 \\
\hline Spider nevi & 02 & 1.7 \\
\hline & & \\
\hline
\end{tabular}

Table 4: Distribution of study subjects according to causes of jaundice.

\begin{tabular}{|c|c|c|}
\hline \multicolumn{3}{|l|}{ Causes specific to pregnancy } \\
\hline $\begin{array}{l}\text { Preeclampsia related } \\
\text { disorders }\end{array}$ & 41 & 36.28 \\
\hline Preeclampsia & 27 & 65.8 \\
\hline Eclampsia & 14 & 34.1 \\
\hline HELLP syndrome & 41 & 100 \\
\hline Acute fatty liver of pregnancy & 10 & 8.84 \\
\hline $\begin{array}{l}\text { Intrahepatic cholestasis of } \\
\text { pregnancy }\end{array}$ & 02 & 1.76 \\
\hline \multicolumn{3}{|c|}{ Causes co-incidental to pregnancy } \\
\hline Viral hepatitis & 37 & 32.7 \\
\hline $\mathrm{HBV}$ & 01 & 2.7 \\
\hline $\mathrm{HCV}$ & 02 & 5.4 \\
\hline $\mathrm{HEV}$ & 34 & 91.8 \\
\hline \multicolumn{3}{|l|}{ Pre-existing liver disease } \\
\hline $\begin{array}{l}\text { Cirrhosis and portal } \\
\text { hypertension }\end{array}$ & 01 & 0.8 \\
\hline Hemolytic jaundice(sickle) & 21 & 18.5 \\
\hline \multicolumn{3}{|c|}{ Congenital hyper-bilirubinemia } \\
\hline Gilberts syndrome $\quad 01$ & & 0.8 \\
\hline
\end{tabular}

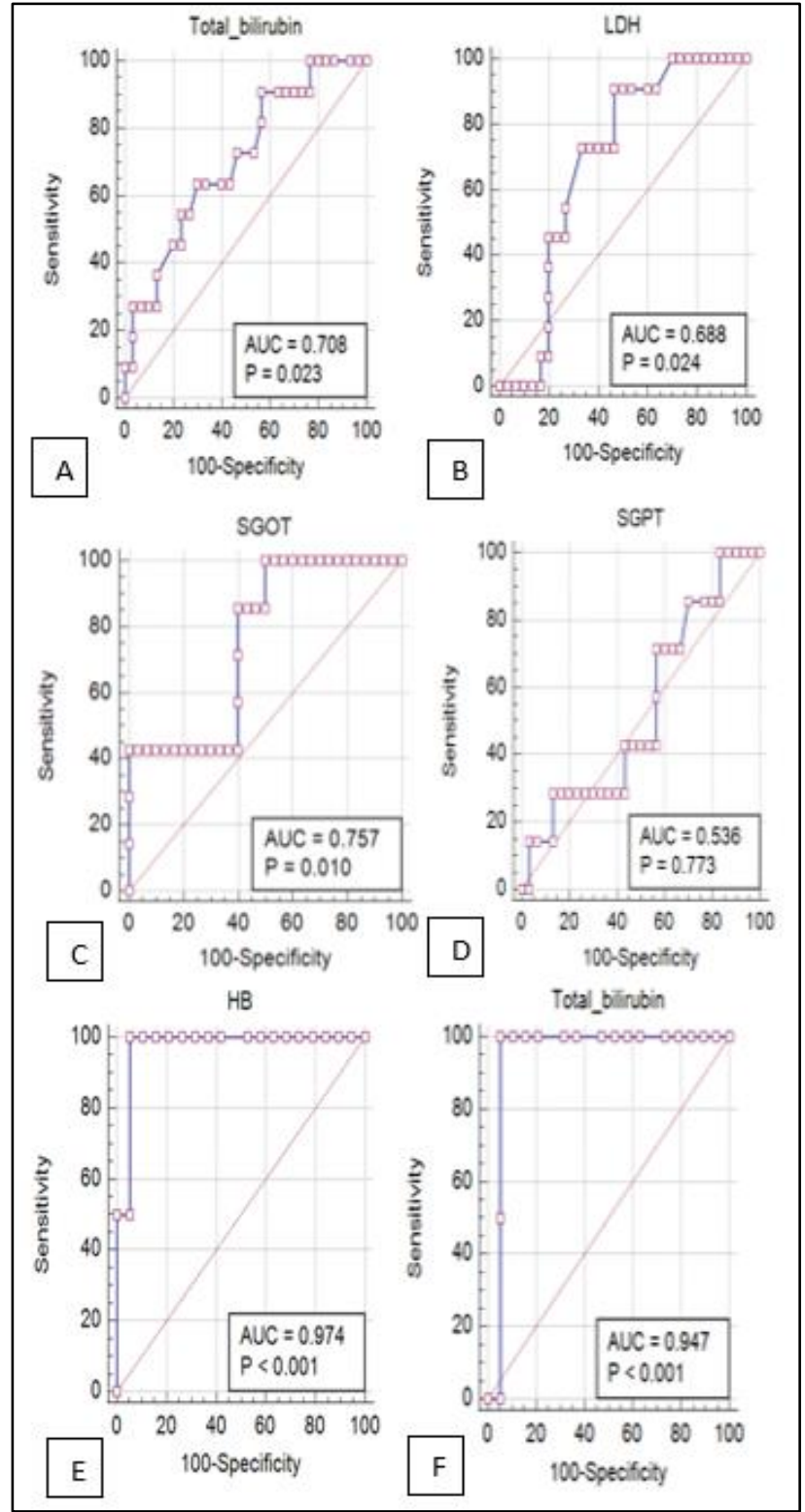

Figure 1: ROC curve analysis. (A) ROC curve analysis of predictive performance of total serum bilirubin with maternal mortality as primary outcome in preeclampsia related disorders. (B) ROC curve analysis of predictive performance of serum $\mathrm{LDH}$ and maternal mortality as primary outcome in preeclampsia related disorders. (C) ROC curve analysis of predictive performance of serum AST and maternal mortality as primary outcome in viral hepatitis. D) ROC curve analysis of predictive performance of serum ALT and maternal mortality as primary outcome in viral hepatitis. (E) ROC curve analysis of predictive performance of hemoglobin and maternal mortality in hemolytic jaundice. (F) ROC curve analysis of performance of total bilirubin and maternal mortality in haemolytic jaundice. 
Table 4 highlights the most common causes of hepatic dysfunction encountered in the study population. Pregnancy specific liver disorder (46.9\%) was the most common cause of Jaundice in pregnancy in current study. HELLP syndrome $(36.2 \%)$ was commonest cause seen in pregnancy specific group. Among the cause's coincidental to pregnancy, viral hepatitis was the most common cause in $32.7 \%$ of patients. The common causes of viral etiologies in decreasing order of frequency were hepatitis E (91.8\%), HCV (5.4\%), HBV (2.7\%). In preexisting liver disorders, hemolytic jaundice due to sickle cell anemia was seen in $18.5 \%$ of patients while one patient had cirrhosis and portal hypertension. One patient had congenital hyperbilirubinemia due to Gilberts syndrome.

Table 5 enlists laboratory investigations observed. The highest level of serum total bilirubin was seen in patients with AFLP, while the highest level of AST and ALT was seen in viral hepatitis. Mean hemoglobin and platelet counts were lowest in patients with HELLP syndrome.

Out of 113 study subjects in our study population, 2 patients with viral hepatitis (1.76\%) underwent spontaneous abortion, 107 (96.4\%) women delivered. Two antenatal women with hemolytic jaundice improved and discharged while two expired undelivered, out of which one had AFLP while other was diagnosed with viral hepatitis. The preferred mode of delivery was vaginal $(73.8 \%)$ while LSCS was done in $24.2 \%$ of the study subjects, rest two underwent instrumental delivery.

Receiver operating characteristic (ROC) curve of maternal levels of hemoglobin, platelet counts, total bilirubin, INR, AST, ALT and LDH in individual causes of jaundice were plotted.

In preeclampsia related disorders and HELLP syndrome, the area under the ROC (AUROC) for bilirubin (0.708) $(\mathrm{p}=0.02)$ with a threshold level of $>4.8 \mathrm{mg} / \mathrm{dl}$ with $90 \%$ sensitivity and $43.3 \%$ specificity, serum LDH (0.688) ( $\mathrm{p}=0.02$ ) with a threshold level of $>884 \mathrm{IU} / \mathrm{L}$ with $90 \%$ sensitivity and $53.3 \%$ specificity were found superior to platelet count and INR as outcome predictor.

In relation to Acute viral hepatitis the area under the ROC for serum bilirubin $(0.7)(\mathrm{p}=0.13)$, serum AST (0.757) $(\mathrm{p}=0.01)$ and serum ALT $(0.65)(\mathrm{p}=0.10)$, serum AST was found superior as adverse outcome predictor with a threshold of $>548$ having $100 \%$ sensitivity and $50 \%$ specificity.

In hemolytic jaundice, both hemoglobin level and total bilirubin were found statistically significant as outcome predictor with $\mathrm{p}<0.0001$, the threshold of hemoglobin $<5.1 \mathrm{mg} \%$ having $100 \%$ sensitivity and $94 \%$ specificity and the threshold of bilirubin $>6 \mathrm{mg} / \mathrm{dl}$ having $100 \%$ sensitivity and $94 \%$ specificity.

Table 5: Laboratory investigations in various etiologies of jaundice.

\begin{tabular}{|c|c|c|c|c|c|}
\hline Etiology & HELLP \% (n) & AFLP \% (n) & IHCP \% (n) & $\begin{array}{l}\text { Viral } \\
\text { hepatitis \% (n) }\end{array}$ & $\begin{array}{l}\text { Hemolytic } \\
\text { Jaundice \% (n) }\end{array}$ \\
\hline \multicolumn{6}{|l|}{ Parameter } \\
\hline \multicolumn{6}{|c|}{ S. Bilirubin (mg/dl) } \\
\hline$<5$ & $36.5(15)$ & - & $100(2)$ & $8.1(3)$ & $90.4(19)$ \\
\hline $5-<10$ & $58(24)$ & - & - & $45.9(17)$ & $9.5(2)$ \\
\hline $10-15$ & $4.8(2)$ & - & - & $32.4(12)$ & - \\
\hline$>15$ & - & $100(10)$ & - & $13.5(5)$ & - \\
\hline Mean & $5.7 \pm 4.6$ & $15.4 \pm 4.7$ & $5.4 \pm 1.4$ & $9.3 \pm 4.7$ & $4.6 \pm 4.7$ \\
\hline \multicolumn{6}{|l|}{ AST (IU/L) } \\
\hline$<100$ & $26.8(11)$ & $10(1)$ & $50(1)$ & $2.7(1)$ & 90.4 (19) \\
\hline $100-<500$ & $63.4(26)$ & $50(5)$ & $50(1)$ & $24.3(9)$ & $9.5(2)$ \\
\hline $500-<1000$ & $9.7(4)$ & $20(2)$ & - & $54(20)$ & - \\
\hline$>1000$ & - & $20(2)$ & - & $18.1(7)$ & - \\
\hline Mean & $194.9 \pm 370.8$ & $518.1 \pm 379.7$ & $103.3 \pm 66.0$ & $646.8 \pm 379.3$ & $70.1 \pm 388.0$ \\
\hline \multicolumn{6}{|c|}{ ALT (IU/L) } \\
\hline$<100$ & $39(16)$ & $10(1)$ & $100(2)$ & $5.4(2)$ & 90.4 (19) \\
\hline $100-<500$ & $53.6(22)$ & $50(5)$ & - & $24.3(9)$ & $9.5(2)$ \\
\hline $500-<1000$ & $7.3(3)$ & $30(3)$ & - & $51.3(19)$ & - \\
\hline$>1000$ & - & $10(1)$ & - & $18.9(7)$ & - \\
\hline Mean & $144.9 \pm 346.5$ & $480.1 \pm 343.0$ & $54.2 \pm 115.2$ & $614.3 \pm 351.5$ & $54.4 \pm 115.2$ \\
\hline \multicolumn{6}{|c|}{ Platelet count $\left(\mathrm{lac} / \mathrm{mm}^{3}\right)$} \\
\hline$<50,000$ & $17(7)$ & $20 \%(2)$ & - & $2.7(1)$ & $2.7(1)$ \\
\hline $50,000-<1$ & $60.9(25)$ & $20(2)$ & - & $8.1(3)$ & $9.5(2)$ \\
\hline $1-<1.5$ & $14.6(2)$ & $20(2)$ & - & $16.2(6)$ & $9.5(2)$ \\
\hline$>1.5$ & $17.7(7)$ & $40(4)$ & $100(2)$ & $87(27)$ & $76.1(16)$ \\
\hline Mean & $106.5 \pm 106.1$ & $125.3 \pm 111.6$ & $376.5 \pm 141.5$ & $270.3 \pm 104.6$ & $212.7 \pm 105.8$ \\
\hline
\end{tabular}

Continued. 


\begin{tabular}{|c|c|c|c|c|c|}
\hline Etiology & HELLP \% (n) & AFLP \% (n) & IHCP \% (n) & $\begin{array}{l}\text { Viral } \\
\text { hepatitis \% (n) }\end{array}$ & $\begin{array}{l}\text { Hemolytic } \\
\text { Jaundice \% (n) }\end{array}$ \\
\hline \multicolumn{6}{|c|}{ Hb (gm\%) } \\
\hline$<4$ & 0 & 0 & - & $5.4(2)$ & 0 \\
\hline $4-6.9$ & $33.3(7)$ & $30(3)$ & - & $13.5(5)$ & $23.8(5)$ \\
\hline $7-8.9$ & $21.9(9)$ & $10(1)$ & $50(1)$ & $21.6(8)$ & $47.6(10)$ \\
\hline $9-10.9$ & $39.02(16)$ & $40(4)$ & $50(1)$ & $35.1(13)$ & $23.8(5)$ \\
\hline$>11$ & $21.9(9)$ & $20(2)$ & - & $24.3(9)$ & $4.7(1)$ \\
\hline Mean & $9.2 \pm 2.6$ & $9.1 \pm 2.8$ & $9.9 \pm 1.5$ & $9.4 \pm 2.5$ & $7.1 \pm 2.6$ \\
\hline
\end{tabular}

Table 6: Distribution of study subjects as per maternal complications in various causes of jaundice.

\begin{tabular}{|c|c|c|c|}
\hline \multirow{3}{*}{ Disease } & \multicolumn{3}{|l|}{ Maternal complication \% (n) } \\
\hline & \multicolumn{2}{|l|}{ Obstetric } & \multirow{2}{*}{ Medical } \\
\hline & Antenatal & Postnatal & \\
\hline \multicolumn{4}{|c|}{ Causes unique to pregnancy } \\
\hline \multirow{5}{*}{$\begin{array}{l}\text { Preeclampsia } \\
\text { related disorder } \\
(\mathrm{n}=41)\end{array}$} & APH (Abruption)-9.7 (4) & Atonic PPH-24.3 (10) & ARDS-2.4 (1) \\
\hline & Preterm labor-58.5 (24) & DIC-9.7 (4) & MODS-9.7 (4) \\
\hline & PROM-21.9 (9) & & Hepato-renal syndrome-14.6 (6) \\
\hline & Prolong labor-7.3 (3) & & Sepis-2.4 (1) \\
\hline & & & Hemorrhagic shock-2.4 (1) \\
\hline \multirow{6}{*}{$\begin{array}{l}\text { Acute fatty liver } \\
\text { of pregnancy } \\
(n=10)\end{array}$} & APH (abruption grade 4)-10 (1) & Atonic PPH -50 (5) & ARDS-20 (2) \\
\hline & Preterm labor-70 (7) & Puerperal sepsis-20 (2) & MODS-30 (3) \\
\hline & PROM-30 (3) & & Hepatorenal syndrome-20 (2) \\
\hline & Prolong labor-40 (4) & & $\begin{array}{l}\text { Hepatic } \\
\text { encephalopathy-40 (4) }\end{array}$ \\
\hline & & & Fulminant hepatic failure-10 (1) \\
\hline & & & Sepsis-20 (2) \\
\hline $\begin{array}{l}\text { Intra hepatic } \\
\text { cholestasis of } \\
\text { pregnancy }(n=2)\end{array}$ & & Atonic PPH-50 (1) & Wound infection-50 (1) \\
\hline \multicolumn{4}{|c|}{ Causes coincidental to pregnancy } \\
\hline \multirow{7}{*}{$\begin{array}{l}\text { Viral hepatitis } \\
(\mathrm{n}=37)\end{array}$} & APH (grade 3 abruption)-8.1 (3) & PPH-2.7 (1) & ARDS-5.4 (2) \\
\hline & Preterm labor-45.9 (17) & DIC-16.2 (6) & Hepatic encephalopathy-16.2 (6) \\
\hline & PROM-35.1 (13) & & Hepatorenal syndrome-10.8 (4) \\
\hline & Abortion $($ spontaneous $)=5.4(2)$ & & Fulminant hepatic failure-16 \\
\hline & Prolong labor-13.5 (5) & & Wound infection-2.7 (1) \\
\hline & & & Sepsis-8.1 \\
\hline & & & $\begin{array}{l}\text { Hemorrhagic shock } \\
\text { (Coagulopathy)-5.4 (2) }\end{array}$ \\
\hline \multicolumn{4}{|c|}{ Pre-existing liver disorders } \\
\hline \multirow{4}{*}{$\begin{array}{l}\text { Hemolytic } \\
\text { jaundice } \\
(n=21)\end{array}$} & Preterm labor-19.04 (4) & PPH-4.7 (1) & Wound infection=4.7 (1) \\
\hline & PROM-23.8 (5) & & Sickle cell crisis-38 (8) \\
\hline & & & Sepsis=4.7 (1) \\
\hline & & & Hemorrhagic shock=4.7 (1) \\
\hline $\begin{array}{l}\text { Chronic liver } \\
\text { disease }(n=1)\end{array}$ & Preterm labor-100 (1) & & \\
\hline \multicolumn{4}{|c|}{ Congenital hyperbilirubinemia } \\
\hline Gilberts $(n=1)$ & Preterm labor-100 (1) & & \\
\hline
\end{tabular}

Table 7: Bivariate analysis of laboratory characteristics with poor maternal outcome as primary outcome.

\begin{tabular}{|llll|}
\hline Variable & Alive $($ Mean \pm 2 SD) & Dead & P value \\
\hline Total serum bilirubin & $6.6 \pm 3.6$ & $11.46 \pm 5.48$ & 0.005 \\
\hline Thrombocytopenia & $1.72 \pm 1.03$ & $1.41 \pm 1.08$ & 0.699 \\
\hline Anemia & $9.3 \pm 2.17$ & $7.5 \pm 3.1$ & 0.009 \\
\hline INR & $1.46 \pm 0.36$ & $1.74 \pm 0.50$ & 0.02 \\
\hline AST & $317.03 \pm 338.3$ & $487.03 \pm 457.17$ & 0.036 \\
\hline ALT & $299.04 \pm 330$ & $405 \pm 392.6$ & 0.235 \\
\hline
\end{tabular}


Bivariate analysis of laboratory characteristics with poor maternal outcome as primary outcome had significant results. Higher total serum bilirubin, INR, serum AST and low hemoglobin level had significant correlation with adverse maternal outcome $(\mathrm{p}=0.005,0.02,0.03$ and 0.009 respectively). However, laboratory values of platelet and serum ALT were not significant as prognostic markers.

\section{DISCUSSION}

Hepatic dysfunction complicates about $3-5 \%$ of pregnancies but it leads to perinatal mortality in $60 \%$ of cases and maternal mortality in 14 to $100 \%$ of cases depending upon the cause. ${ }^{1}$ The present study aimed at analyzing the feto-maternal outcome in presence of jaundice or deranged liver function tests in pregnancy. The various parameters in the study subjects were analyzed and compared with standard literature readings available.

During the study period of two year from September 2018 to September 202015,538 deliveries were conducted in the institute and 113 women had jaundice. The incidence of jaundice in this study was found to be $0.72 \%$ comparable to the results as cited by Satia $(0.81 \%)$ and Jayati et al $(0.95 \%)$ while the incidence was very low in the study done by Sunanda et al $(0.15 \%) .^{4-6}$ Present study was conducted at a tertiary referred care center dealing with referred cases of preeclampsia, HELLP syndrome, hepatitis and chronic liver diseases, besides the area is a belt of sickle cell anemia leading to more number of hemolytic jaundice and during the study period there was an outbreak of hepatitis E.

Most of the women in the present study were of the age of 20-25 years. Other studies also noticed jaundice frequently in the women of same age group because of the period of maximum fertility and early marriages and hence child birth.

$87.6 \%$ of the cases were un-booked as cited in studies by Mitta (93.3\%), Choudhary $(68.9 \%)$ and Jyoti et al $(60.3 \%) .^{7-9}$ This highlights the need of regular antenatal checkup, especially in high-risk cases, to aid early identification of disease and prompt treatment or referral if needed.

Most of the study population $(63.7 \%)$ belonged to low socioeconomic status as also stated by Sharma (60\%) and Mitta et al (57.1). ${ }^{7,10}$ Predominance of poverty in the study subjects underscores the importance of nutrition and sanitation. 34 out of 113 subjects had jaundice due to hepatitis $\mathrm{E}$ which has feco-oral route of transmission.

Most of the women presented with jaundice in their third trimester $(97.3 \%)$ as also stated by Shukla et al, Harshad et al and Krishnamurthy et al because most of the pregnancy specific liver disorders like HELLP syndrome and AFLP are seen in last trimester whereas infective and hemolytic jaundice can happen in any trimester of pregnancy. $5,11,12$

Yellowish discoloration of urine and sclera (48.6\%) were the most common presenting symptoms with which the study subjects presented, probably it was most noticeable symptom, while myalgia and fever occurred in only $21.2 \%$ of the cases. Mitta $(59.5 \%)$, Sharma $(60.67 \%)$ and Nagaria et al (48.48\%) also stated yellowish discoloration of urine and sclera as the most common symptom in their studies. $^{7,10,13}$

Pallor (100\%) and Icterus (98.2\%) were the most common signs in the study population while the least common signs were scratch marks, hepatomegaly, splenomegaly, palmer erythema and spider nevi. Vani (64\%), Mitta (100\%) and Sandhya et al (100\%) also observed pallor and icterus as the most common sign in their studies. ${ }^{7,14,15}$ This may be due to the reason that icterus is seen earlier in the disease while scratch marks, hepatomegaly and splenomegaly are noticed in advanced stage.

Most common cause of jaundice in present study was HELLP syndrome in $36.2 \%$ of cases, as also stated by Reddy et al (33.3\%) and Choudhary et al (46.55\%). ${ }^{8,16}$ Present study was conducted in a tertiary care referred hospital where large number of women with HELLP and AFLP are referred.

Hepatitis E (91.8\%) was the most common type of viral hepatitis in the study subjects. This is because there was an outbreak of acute hepatitis $E$ in the area during the study period. Choudhary $(45.4 \%)$, Praveen $(80.4 \%)$ and Singla $(43.9 \%)$ also noticed HEV being the commonest in their studies, while study by Sharma and Mitta P et al found Hepatitis $\mathrm{B}$ as the most common type of viral hepatitis in 26.7 and $77.2 \%$ cases respectively. ${ }^{7,8,10,17,18}$ Routine screening of all antenatal women for hepatitis B and awareness towards vaccination programme was the reason that present study had only one study subject with acute viral hepatitis B.

This part of central India is the belt for sickle cell anemia and hence $18.5 \%$ women in present study had hemolytic jaundice while Krishnamoorthy $\mathbf{J}$ et al reported only one case of hemolytic jaundice in their study that too due to hereditary spherocytosis. ${ }^{5}$

Various liver function tests were ordered to estimate the severity of disease. Mean total serum bilirubin was lowest in study subjects with hemolytic jaundice (4.65 $\mathrm{mg} / \mathrm{dl})$ and it was highest in subjects with acute fatty liver of pregnancy $(15.4 \mathrm{mg} / \mathrm{dl})$, while in the study by Indrajit et al lowest mean serum bilirubin was seen in study subjects with preeclampsia $(1.2 \mathrm{mg} / \mathrm{dl})$ and highest in viral hepatitis $(2.8 \mathrm{mg} / \mathrm{dl}) .{ }^{19}$ Maximum total serum bilirubin was seen in patients with viral hepatitis in study by Mishra et al and in subjects with HELLP syndrome by Bhalla et al. Present study observed highest bilirubin in 
subjects with AFLP as this was one of the cause with fulminant course of disease which deteriorates very fast. $^{1,20}$

Present study observed highest levels of serum AST (646.8 IU/L) and ALT (614.3 IU/L) in viral hepatitis while the values were lowest in hemolytic jaundice. AST and ALT levels shows the degree of liver impairment and hence values were lowest in hemolytic jaundice Mishra et al had consistent findings with highest level of mean serum AST (741.4 IU/L) and ALT (814 IU/L) in infective hepatitis and lowest in preeclampsia related disorders. ${ }^{20}$

Marked elevation of alkaline phosphate $>1000$ IU/L with a mean of $1680 \mathrm{IU} / \mathrm{L}$ was found in Obstetric cholestasis. Comparable results were cited by the study done by Khatuja et al in which high level of alkaline phosphate was found in all the cases of IHCP. ${ }^{21}$

In the present study, mean serum LDH was highest in acute fatty liver of pregnancy (1339 IU/L), while it was lowest in intra hepatic cholestasis of pregnancy (275 IU/L). However, Mishra et al stated highest level of serum LDH in HELLP syndrome and lowest in viral hepatitis. ${ }^{20}$ AFLP is an entity which has overlapping presentation with HELLP syndrome and hence often underdiagnosed or misdiagnosed as HELLP.

$80.5 \%$ of the study subjects were anemic in the present study. Out of which $19.4 \%$ were severely anemic. Patel and Suresh et al reported anemia in 30.5 and $37 \%$ of pregnant women. ${ }^{19,22}$ Hemolysis was the major cause of anemia seen in $30,33.3$ and $23.8 \%$ of the study subjects with AFLP, HELLP syndrome and sickle cell disease.

Thrombocytopenia was observed mainly in patients of HELLP syndrome. Among the preeclampsia related disorders $60.9 \%$ of study subjects had platelet count between 50,000-1 lac and $17 \%$ had platelet count less than $50,000 / \mathrm{mm}^{3}$. Similar results were cited in the studies done by Suresh and Bhalla et al where mean hemoglobin $(10.1 \mathrm{mg} \%, 7.33 \mathrm{mg} \%)$ and platelet counts $\left(1 \mathrm{lac} / \mathrm{mm}^{3}\right.$, $1.07 \mathrm{lac} / \mathrm{mm}^{3}$ ) were lowest in patients of HELLP syndrome. ${ }^{1,19}$ However, in the study done by Patel et al thrombocytopenia was found in only $16.3 \%$ of patients. ${ }^{22}$ This may be attributed to the fact that majority of the study subjects in this study had infective hepatitis (44.8\%) and HELLP syndrome cases were only $18.3 \%$.

Spectrum of obstetric complications varies with the etiology of jaundice in pregnancy. In our study, the major obstetric complications associated with preeclampsia related disorders were preterm labor $(58.5 \%)$, PROM (21.9\%), prolonged labor (7.3\%), abruption (9.7\%), DIC $(9.7 \%)$ and atonic PPH $(24.3 \%)$. Suresh et al observed placental abruption in only $2 \%$ of the HELLP cases. ${ }^{19}$ This represents advanced course of the disease in present study with higher levels of mean serum bilirubin $(5.7 \pm 4.6$ $\mathrm{mg} / \mathrm{dl}$ ) as compared to study by Suresh et al (mean bilirubin 1.3 \pm 1.5$)$. Among the medical complications
$14.6 \%$ underwent hepatorenal syndrome, $9.7 \%$ suffered from multi organ failure while ARDS, sepsis and hemorrhagic shock was seen in $2.4 \%$ cases each. None of the other studies had discussed medical complications in individual causes of jaundice.

Stress induces labor therefore $70 \%$ of the study subjects with acute fatty liver of pregnancy went into Preterm labor, 30\% had prolonged labor, 10\% patients had abruption, 50\% Atonic PPH, and 20\% puerperal sepsis. Among the medical complications hepatic encephalopathy occurred in $40 \%$ of the study subjects followed by multi organ failure in $30 \%$ of cases. These findings emphasizes that AFLP is the entity which deteriorates very fast and leads to many medical complications in the mother.

IHCP carries a benign course but one of the patients had atonic PPH which was managed with medical methods and other women had wound infection which was managed conservatively. Ch'ing et al reported that fetomaternal complications were lesser in IHCP as compare to other etiologies of hepatic dysfunction. ${ }^{23}$ This finding is consistent in our study too.

A total $45.9 \%$ of women in acute viral hepatitis had preterm labor. Other complications were DIC (16.2\%) and hepatic encephalopathy $(16.2 \%)$ and fulminant hepatic failure (16\%). Our findings are consistent with the study done by Sushmita et al and Saima et al where preterm labor was identified as most common complication of viral hepatitis in $39 \%$ and $33 \%$ of cases respectively. ${ }^{24,25}$ Fulminant hepatic failure was seen in 6 out of 34 patients with Hepatitis E in this study while it was seen in only one patient with hepatitis C. Singla et al reported fulminant hepatic failure in $80 \%$ of women with hepatitis $\mathrm{E}$ in their study. ${ }^{18}$

Our study observed $63.4 \%$ live births in cases of HELLP while Sunanda et al showed higher live births of $70 \%$, as present study had $48.7 \%$ of HELLP subjects who were very critical and required ICU admission at the outset suggesting for the graver prognosis. ${ }^{6}$ Vemu et al had comparable live births while Jayanti et al showed live births of $32.1 \%$ which is much lower than present study probably because of less study population in HELLP group in their study. 5,14

As present study observed fetal outcome in individual cause of jaundice, it observed $44.4 \%$ live births in cases of AFLP which is much higher than Sunanda et al showing $100 \%$ fetal mortality. Early diagnosis and intervention by Swansea criteria have led to better outcome of fetuses.

The definitive management of a patient with HELLP syndrome is delivery of fetus, therefore significant number of babies born were preterm $(58.5 \%)$ our data is comparable to Bhalla et al showing $50 \%$ of preterm births in women with HELLP while in study of Indrajit et al 
$63 \%$ preterm births were seen, which is higher than ours because in our study more HELLP cases were admitted in advanced gestational age. ${ }^{1,19}$

In present study, live births in viral hepatitis were $67.6 \%$ with fetal death rate of $32.2 \%$, these findings are lower than data of Sunanda et al where live births are $100 \%$, as $91 \%$ of our study population had hepatitis E which has poor outcome while $63 \%$ in Sunanda et al had hepatitis E.

There is paucity of data in literature regarding predictors of adverse maternal outcome in pregnancies complicated by jaundice. So, the present study tried to find relationship of maternal levels of hemoglobin, platelet count, total bilirubin, INR, AST, ALT, and LDH with maternal outcome in individual causes of jaundice. In preeclampsia related disorder, serum bilirubin and LDH were found superior to platelet count and INR as outcome predictor. In acute viral hepatitis, serum AST was found superior as a predictor of adverse maternal outcome in comparison to ALT and total bilirubin, whereas, in hemolytic jaundice both hemoglobin level and total serum bilirubin were found statically significant as outcome predictor. None of the other authors have studied ROC based data in individual causes of jaundice.

On applying bivariate analysis of laboratory characteristics with adverse maternal outcome, higher total serum bilirubin, INR, serum AST and low hemoglobin had significant correlation as prognostic markers. However, Bhalla et al validated only low maternal hemoglobin and INR as a predictor of maternal adversity. ${ }^{1}$

\section{Limitations}

The above study has been done in a small subset of population, so for generalization of results large multicentric studies are required.

\section{CONCLUSION}

Though HELLP syndrome and Viral hepatitis are preventable causes of jaundice yet it contributes to significant proportion of maternal deaths in 26.5 and $18.5 \%$ cases respectively. Timely antenatal care, proper sanitation and awareness towards vaccination can prevent this subset of illness. AFLP being a genetic disorder, is often under diagnosed has a fulminate course in pregnancy. Early diagnosis, prompt treatment in ICU facility and multidisciplinary approach can save $40 \%$ of neonates.

Maternal laboratory parameters like total bilirubin, hemoglobin, LDH, SGOT, SGPT serve as significant outcome predictors. These can be used by health care workers in peripheries to refer such patients to advanced health care. Availability of blood products and ICU facilities has revolutionized the management of jaundice. Due to involvement of multiple systems, it is essential that we provide these women with multidisciplinary care to cause an impact in preventing feto-maternal morbidity and mortality.

\section{ACKNOWLEDGMENTS}

The author would like to thank all the study subjects who had given consent to participate in the study.

Funding: No funding sources

Conflict of interest: None declared

Ethical approval: The study was approved by the Institutional Ethics Committee

\section{REFERENCES}

1. Bhalla S, Bhatti SG, Kumar S, Kaur P. Predictors of Feto-Maternal Outcome in Pregnancies Complicated by Hepatic Dysfunction: Observational study in a tertiary care hospital in Punjab. Pan Asian J Obs Gyn. 2019;2(1):12-21

2. Creasy RK, Reshik R. Jaundice. In: Creasy RK; Reshik R; eds. Maternal and fetal medicine: Principles and Practice. 5th ed. Philadelphia; WB Saunders. 2014:713.

3. Raghunandan C. Jaundice in Pregnancy. In: Trivedi SS, Puri M (editors). Management of High-Risk Pregnancy: A Practical Approach. Jaypee Medical Publishers (P) Ltd, New Delhi. 2010;348-68.

4. Satia MN. A study of fetomaternal outcomes in cases of jaundice at a tertiary care centre. Int $\mathrm{J}$ Reprod Contracept Obstet Gynecol. 2016;5(7):2352-7.

5. Krishnamoorthy J, Murugesan A. Jaundice during pregnancy-maternal and fetal outcome. Int J Reprod Contracept Obstet Gynecol. 2016:5(8):2541-5.

6. Sunanda KM, Jois SK, Suresh S. A study of outcome of induction of labour with foley's balloon in previous LSCS cases. Int J Reprod Contracept Obstet Gynecol. 2017;4(3):230-4

7. Mitta P, Rao SV. Fetoomaternal outcome in jaundice complicating pregnancy. J Dent Med Sci. 2016;15(10)(VI):72-6.

8. Choudhary N, Sen S, Varalakshmi K. A prospective study on pregnancy complicated with jaundice with special emphasis on fetomaternal outcome. Int $\mathbf{J}$ Reprod Contracept Obstet Gynecol. 2017;6:5081-8.

9. Jyothi GS, Chakraborty A, Swarup A. A study of fetomaternal outcome of jaundice in pregnancy. Int $\mathbf{J}$ Reprod Contracept Obstet Gynecol. 2018;7:2628-33.

10. Sharma S, Aherwar R, Jawade S. Maternal and fetal outcome in jaundice complicating pregnancy: a prospective study. Int J Reprod Contracept Obstet Gynecol. 2016;5:1084-7.

11. Shukla S. Prospective study on acute viral hepatitis in pregnancy; seroprevalence and fetomaternal outcome of 100 cases. J Bio Sci Tech. 2011;2(3):279-86.

12. Harshad D, WalterKK Ross D. Pregnancy-associated acute liver disease and acute viral hepatitis: 
differentiation, course and outcomes. J Hepatol. 2008;49:930-5.

13. Nagaria T, Agarwal S. Fetomaternal outcome in jaundice during pregnancy. J Obstet Gynecol India. 2005;55(5):424-7.

14. Vani YJ. A study of etiological factors and fetomaternal outcome in jaundice complicating pregnancy at tertiary care centre. J Dental Med Sci. 2017;16(11):36-9.

15. Sandhya Devi KVSM, Bhavani YVL. A comprehensive study on jaundice in pregnancy with emphasis on fetomaternal outcome. IAIM. 2019;6(6):18-22.

16. Reddy MG, Prabhakar GC, Sree V. Maternal and fetal outcome in jaundice complicating pregnancy. JNTR Univ Health Sci. 2014;3:231-3.

17. Praveen T, Begum F, Akhtar N. Fetomaternal outcome of jaundice in pregnancy in a tertiary care hospital. Mymensingh Med J. 2015;24(3):528-36.

18. Singla A, Mehta S, Rajaram S. Materno-Fetal Outcomes with Viral Hepatitis in Pregnancy. J Obstet Gynecol India. 2016;66:166-9.

19. Indrajit S. Predictors of fetal and maternal outcome in the crucible of hepatic dysfunction during pregnancy. Gastroenterol res. 2017;10(1):21-7.

20. Mishra N, Mishra VN, Thakur P. Study of Abnormal Liver Function test during pregnancy in a Tertiary
Care Hospital in Chhattisgarh. J Obstetr Gynecol India. 2016;66(S1):S129-35.

21. Khatuja R. Still to far to walk: A review of maternal mortality in a district hospital. JMSCR. 2019;07:5.

22. Patel BJ, Thaker RV, Shah JM, Mewada BN. Study of feto-maternal outcome in patients of jaundice in third trimester of pregnancy. Int J Reprod Contracept Obstet Gynecol. 2015;4:1961-4.

23. Ch'ng CL, Morgan M, Hainsworth I, Kingham JGC. Prospective study of liver dysfunction in pregnancy in Southwest Wales. Gut. 2002;51:876-80.

24. Sethi DS, Prasad DS. Study to determine the fetal and maternal outcome in acute viral hepatitis. IJMBS, 2019;3:188-92.

25. Wani S, Ajaz S, Jeelani B. Prevalence of viral infections in high-risk pregnancies. Int $\mathrm{J}$ Contemporary Med Res. 2019;6(4):98.

Cite this article as: Kishore R, Thakur N, Tuwani M. Evaluation of maternal and fetal outcome in pregnancies complicated by jaundice-an observational study. Int J Reprod Contracept Obstet Gynecol 2021;10:1384-92. 